\title{
JUURNAL.RU
}

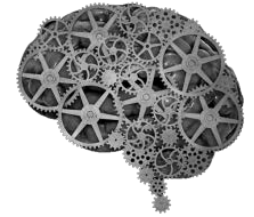

COMPANY GROUP "INTELLEKT"

Киселева А.В. Уральский государственный архитектурно-художественный университет Екатеринбург, Россия

doi: 10.18411/lj2016-3-58

\section{К вопросу о самостоятельной работе и творческой самостоятельности студентов архитектурно-художественнго университета}

Искусство всегда органически связано с индивидуальностью и личностью художника. Чтобы произведения искусства были неповторимы, для этого необходимо постоянное познание реального мира. Окружающее пространство одно из важных образных толкований в мире искусства, оказывающее большое влияние на формирование художественно-образного мышления обучающегося и его творческих способностей, которые являются главной составляющей будущей профессии студентов архитектурно-художественного университета.

«Образное мышление» это процесс взаимосвязи логического, интуитивного и эмоционально-чувственного компонентов с художественным познанием, продуктом которого является «изображение, выполненное в художественном материале, отражающее способность личности анализировать, выделять в предметах и явлениях окружающей действительности наиболее значимое, существенное, обобщать, сочинять художественно-значимый образ и переводить идеально сложившиеся образы на язык искусства» [8, с. 121]. В педагогической науке накоплен большой опыт методов, способов и приемов для формирования художественно-образного мышления студента, одним из которых, несомненно, является самостоятельная работа, способная раскрыть творческий потенциал студента и обеспечить художественную интерпретацию окружающей реальности. 
Образное мышление определяется широтой специализации: как проявление творческого мышления, интеллекта и мировоззренческих позиций, которые в свою очередь основываются на инициативности, способности к нестандартным решениям и уверенности в своих силах. Художественнообразное мышление представляет собой один из компонентов сознания, занимающих основное место в творческой деятельности. Исследованием вопросом развития творческой деятельности занимались многие известные ученые и педагоги: А.Н. Леонтьев Л.С. Выготский, Б.Г. Ананьев , С.Л. Рубинштейн, В.С. Кузин, Т.С. Комаров, Р.С. Немов, Б.М. Теплов и др.

По мнению В.С. Кузина, творческая деятельность - это совокупность психических свойств, качеств личности человека и его работоспособность, которые необходимы для совершения определенного вида задания. Например, выполнения архитектурного проекта или графического художественноживописного произведения [3].

Вопрос развития творческих способностей студентов в ходе самостоятельной работы на сегодняшний день является актуальной в подготовке будущих профессионалов. Творческая самостоятельность студентов - это стремление к применению новых приемов в процессе овладения профессиональными навыками, поиск путей преодоления затруднений, потребность вносить элементы новизны в выполнение учебных заданий [2].

Основой творческой самостоятельности, по определению, является творчество. Творчество достаточно многомерное и многообразное понятие. Бетти Эдвардс считает, что «творчество - это часть всего нашего существования, нашего тела, нашего разума, эмоций и духа» [11, с.165]. Я.А. Пономарев предлагает говорить не только о творчестве человека, но и о «творчестве природы», это, по его мнению, разные сферы творчества. [5. с.42]. Большинство ученых и психологов согласны с определением, данным А.Г. Спиркиным «Творчество - это духовная деятельность, результатом которой является создание оригинальных ценностей, установление новых, ранее 
неизвестных фактов, свойств и закономерностей материального мира и духовной культуры» [9, с.193].

Поэтому самостоятельная деятельность это постоянный поиск индивидуального «творческого стиля» будущего профессионала, нахождение нового неповторимого и конкретного способа осуществления своего замысла, а также способность виденья в окружающей реальности всех переменных.

Творческая самостоятельность студентов в научно-педагогической литературе понимается как процесс поэтапного сокращения доли помощи со стороны преподавателя в реализации учебно-творческой деятельности студента, расширение сферы применения формируемых умений, знаний, действий и отношений в профессионально-практической деятельности, постепенный переход от заданий репродуктивного (воспроизводящего) характера к творческим заданиям. По мере развития творческой самостоятельности студентов происходит усложнение видов и заданий, самостоятельно выполняемых ими, что влияет на развитие художественно-творческого мышления и проявления устойчивых мотивов учебно-творческой деятельности студентов [4].

Рассматривая психологические механизмы творческой деятельности Ю.Б. Борев выделяет воображение, память и вдохновение. «Художественная память» формируется у каждого человека, но она носит избирательный и творческий характер. Художник, запоминая явления и объекты окружающего мира, создает из них художественные образы. «Художественная одаренность сказывается в избирательности памяти, в выборе объектов, достойных художественного внимания, в умении доставать из памяти впечатления и создавать из них систему ассоциаций и связей, диктуемых творческим воображением» [1, с.178]. С.Л. Рубинштейн, исследуя процесс творческой деятельности, утверждает, что реализация замысла предполагает длительное собирание и осмысление пережитых впечатлений. Для воплощения созданного образа в произведение необходимо изменить впечатления, полученные от наблюдения [6]. Потому 
творческое воображение необходимо студенту, занимающемуся творческой деятельностью.

Многие преподаватели в качестве одной из форм самостоятельной работы предлагают запоминать впечатления, полученные в окружающем пространстве, а затем в мастерских воспроизводить по памяти. Хорошо развитое воображение помогает в изучении направлений и стилей в искусстве, понимать, ощущать и создавать совершенно новые виды реальности, диктующие современным изменением пространства в мире.

Результатом творческой самостоятельной деятельности обучающегося должен стать высокий уровень прогнозирования собственной профессиональной деятельности: студент самостоятельно способен выполнить проект полностью опираясь на свои умения и знания, способен поставить цель, сформулировать проблему, спланировать этапы ее разрешения, находить способы контроля своей работы [7].

Для обеспечения условий развития творческих способностей, необходима тесная взаимосвязь в овладении теоретическим материалом и практикотехническими приемами. Получая необходимые теоретические знания, обучающимся в архитектурно-художественном университете необходимо работать над развитием своих способностей. Поэтому, для поддержания студентов в определенной форме по дальнейшему развитию художественнообразного мышления и творческих способностей, необходимы постоянные занятия творчеством, основанные на мотивации, желании учиться и самосовершенствоваться в профессиональном плане, такие как: изучение и анализ технических и художественных приемов, стилей в искусстве, решение композиционных задач, поиск цветового решения для увиденного нового или старого объекта, передача тренировка техники в этюдах и др. Степень развития и быстрота формирования способностей, у каждого студента индивидуальны. Нивелировать это разрыв, одна из главных задач преподавателя творческого вуза. 
Установлено также, что адекватная оценка студентом своих работ способствует самосовершенствованию, самовоспитанию и развитию художественно-творческих способностей. Этот процесс должен четко управляться и контролироваться педагогом. Помогать студентам в объективной оценке своих работ, поддерживать желание в развитие оценочных компонентов и профессиональных способностей в будущей профессиональной деятельности, одна из важных задач преподавателя при организации самостоятельной творческой деятельности. Ему также необходимо определять и направлять процесс обучения, выбирая такую форму работы, которая бы воздействовала на сознание и деятельность студента в творческом процессе. Такому воздействию соответствует форма педагогической установки, с помощью которой определяются и решаются эстетические, творческие и мыслительные задачи [10]. Создание мотивации к обучению, выработка у студентов необходимости в творческой деятельности, а также педагогическое руководство ими в образовательном процессе, является одним из важных условий для формирования и развития творческих способностей, образного мышления и творческой активности, на которые опирается процесс накопления творческого опыта, а не только на овладение определенными знаниями, умениями и навыками.

Новые задачи самостоятельной работы, в основе которой лежит творческая деятельность, должны ориентироваться на будущую профессиональную деятельность и быть связаны с формированием новых индивидуальных и творческих возможностей. 


\section{Литература:}

1. Борев Ю.Б. Эстетика. Учебное пособие. - М.: Политиздат, 1988. -496 с.

2. Ермолаева-Томина Л.Б. Психология художественного творчества, учебное пособие для вузов. - М.: Академический Проект, 2003. - 304 с.

3. Кузин В.С. Психология живописи: учебное пособие для вузов / В.С. Кузин. - М.: ООО Издательский дом «Оникс 21 век», 2005. - 304 с.

4. Пидкасистый П.И. Самостоятельная деятельность учащихся. Дидактический анализ процесса и структуры воспроизведения и творчества. - М.: Педагогика, 1972. - 184с.

5. Пономарев Я. А. Психология творчества и педагогика. - М.: «Педагогика», 1976. $280 \mathrm{c}$.

6. Рубинштейн С. Л. Принцип творческой самодеятельности // Вопросы философии. 1989. № 4. с.89-95.

7. Сластенин В.А. Формирование индивидуального стиля самостоятельной деятельности студентов// Совершенствование подготовки учителя в педвузе. - М., 1980.- 154 с.

8. Словарь Л.С. Выготского / под ред. А.А. Леонтьева; МГУ. - Москва: Смысл, 2010. - 119 с.

9. Спиркин А.Г. «Сознание и самосознание». - М. «Политиздат». 1972. - 303 c.

10. Степанов А.В., Малахов СА, Нечаев Н.Н. «Введение в проектирование»: уч. пособие. - М.: МАРХИ, 1982. - 134с.

11. Эдвардс Бетти. «Откройте в себе художника». - М.: Издательство: Попурри, 2012 г. - 300 с. 